\title{
Incentive Distribution of Specialist Doctors in Government General Hospital
}

\section{Distribusi Insentif Dokter Spesialis di Rumah Sakit Pemerintah}

\author{
Andi Leny Susyanty ${ }^{1}$, Harimat Hendarwan ${ }^{1}$, Amir Su'udi $^{1}$ \\ ${ }^{1)}$ Center for Health Resources and Services Research and Development, Jl.Percetakan Negara 29 Jakarta Pusat 10560 , \\ Indonesia \\ Corresponding author: andileny.s@litbang.kemkes.go.id
}

Submitted: 13 May 2020, Revised: 21 July 2020, Accepted: 20 August 2020

https://doi.org/10.22435/jpppk.v4i2.3310

\begin{abstract}
Maintaining and fulfilling the needs of specialist doctors in government public hospitals is still a challenge. Government general hospitals have not been able to meet the minimum standard for specialist doctors. The distribution of personnel and the incentives received by specialist doctors varies between regions. This study aims to provide recommendations related to policies to meet the needs of specialist doctors at government general hospitals. This cross-sectional research study was conducted in May - December 2017 in 19 hospitals in 18 districts/cities. A total of 134 specialist doctors and dental specialists were respondents in this study. The fulfillment of non-financial incentives for specialist doctors, $28.4 \%$ lived in official homes, $41.8 \%$ received official vehicles and $73.1 \%$ were facilitated to attend seminars/education and training. Fulfillment of financial incentives shows that $73.1 \%$ of their income is sufficient for the family's needs for 1 month and $63.5 \%$ can save. Further east, the incentives received by specialist doctors are greater. The combined capacity of central and local budgets can be optimized to provide adequate and equitable incentives to retain specialist doctors in government hospitals, especially in less desirable areas and with limited budgets.
\end{abstract}

Keywords: adequacy, disparity, incentive

\begin{abstract}
Abstrak
Keberadaan dan kecukupan dokter spesialis di rumah sakit umum pemerintah masih menjadi kendala. Masih banyak rumah sakit yang belum memenuhi standar minimal dokter spesialis di rumah sakit dan masih adanya disparitas distribusi tenaga dan insentif dokter spesialis di tiap daerah. Penelitian ini bertujuan untuk menyediakan rekomendasi kebijakan terkait pemenuhan kebutuhan dokter spesialis dari aspek penyediaan insentif bagi dokter. Penelitian ini dilakukan secara cross-sectional dan dilaksanakan pada bulan Mei Desember 2017 di 19 RS di 18 kabupaten / kota. Sebanyak 134 dokter spesialis dan dokter gigi spesialis yang menjadi responden penelitian ini. Sebanyak 28,4\% tinggal di rumah layanan yang disediakan, 73,1\% dari pendapatannya mencukupi kebutuhan keluarga selama 1 bulan, 63,5\% dapat menabung, 41,8\% dapat kendaraan, 73,1\% telah difasilitasi untuk mengikuti seminar / pendidikan dan pelatihan. Semakin ke timur, insentif yang diterima dokter spesialis semakin besar. Kombinasi kemampuan anggaran pusat dan daerah dapat dioptimalkan untuk memberikan insentif yang memadai dan merata untuk mempertahankan dokter spesialis di rumah sakit pemerintah, terutama di daerah yang tidak diminati dan dengan kendala anggaran.
\end{abstract}

Kata kunci: kecukupan, disparitas, insentif 


\section{Background}

Under the mandate of the Act, the Government and Regional Governments must meet the needs of the health workforce, both in number, type, and competence (Article 13 of Law Number 36 of 2014 concerning Health Workforce). Article 27 paragraph 3 further states, in the event of a vacancy, the Government and the Regional Government shall provide a replacement health workforce. ${ }^{1}$ To fulfill the mandate, there are several mechanisms for the fulfillment of the health workforce that have been established through various regulations. Law Number 5 of 2014 concerning State Civil Apparatus (ASN) article 6 states that ASN employees consist of civil servants (PNS) and Government Employees with Work Agreements (PPPK). Appointment of health workforce through PNS, PPPK, and Special Assignments. Law No. 36 of 2014 also opens opportunities for compulsory work for the health workforce who meet academic qualifications and article competencies (28 paragraph 1). The Government and/or regional governments can establish patterns of official ties (Article 29 paragraph 1). ${ }^{1,2}$

Specialists are a health workforce whose existence is at the forefront of service in hospitals. The existence and adequacy of specialists is part of efforts to meet the needs of the community for specialist health services so that it will increase public access to quality health services. Board for Development and Empowerment Human Health Resources (BPPSDMK) data shows that the ratio of specialists has met the target of the development plan for health workforce with a ratio of 13.6 per 100,000 population (target $10.4 / 100,000$ ), but according to Minister of Health Regulations (Permenkes) 56 in 2014 and Permenkes 340 in 2014 on hospital classification, at least 482 Pediatrician, 369 obstetricians and gynecologists, 408 Internist, 571 Surgeon, 173 Anesthesiologist, 469 Radiologist, 372 Physiatrist (Physical Medicine and Rehabilitation (PM\&R) physicians), and 388 Clinical pathologists are still needed at Government hospitals. ${ }^{3}$

The achievement of the national health workforce development plan target still leaves a disparity of specialists in each province. NTT Province with a ratio of 2.8 per 100,000 population compared to DKI Jakarta Province with a ratio of specialists is 70.6 per 100,000 population. $^{3}$ The government should bridge this gapthrough identifying the needs of specialists in the region, retention affecting factor, calculating the suitability and appropriateness of incentives that specialist doctors are willing to work in areas with certain conditions, as well as appropriate assignment mechanisms for specialist doctors. This study was conducted to provide input for policy making related to meeting the needs of specialist doctors, particularly concerning financial and non-financial incentives.

\section{Method}

This study was conducted in a crosssectional design, with a quantitative approach, and carried out primary and secondary data. The study was conducted in May - December 2017 in 3 regional regions (West, Central, and East) of Indonesia, each region was represented by 2 provinces that have regional hospitals and regional referral hospitals / provincial/national referrals. Based on this, sample hospitals were established in 6 provinces: Riau, Jawa Timur, Kalimantan Barat, Kalimantan Tengah, Maluku, and Papua. The selection of provinces for study locations was carried out purposively representing the geographic regions of Western Indonesia (Riau and Jawa Timur), Central Indonesia (Kalimantan Barat and Kalimantan Tengah), and Eastern Indonesia (Papua and Maluku). In each province there are 3 districts / cities that are the study locations, 2 districts and 1 city, so that in total there are 18 districts / cities namely Bangkalis, Kampar, and Kota Pekanbaru (Riau Province), Jombang, Jember, and Kota Surabaya (Jawa Timur Province), Sintang, Singkawang District, and Pontianak City (Kalimantan Barat Province), Barito Utara, Kotawaringin Timur, Kota Palangkaraya City (Kalimantan Tengah Province), Maluku Tenggara, Maluku Tengah, and Ambon City (Maluku Province), Biak-Numfor District, Jayawijaya, and Kota Jayapura (Papua Province). Hospital locations in each province are selected based on national, regional referral hospitals, district/city referral hospitals, and type D hospitals representation in each province. Nineteen hospitals were selected as study locations. Respondents in each hospital consisted of Hospital Director (Hospital Management), 4 
basic medical specialists (Pediatrician, obstetricians and gynecologists, internists, and Surgeons), and 3 other types of specialists (Radiology, ENT, Eye, Anesthesia, Skin and Gender, Clinical Pathology, etc.).

Quantitative data were collected using a study questionnaire containing information on the availability of health human resources (specialist doctors and sub-specialists), the availability of facilities and infrastructure, the need for specialist doctors (financial incentives, home, and transportation). Data analysis was carried out descriptively to obtain the availability and incentive facilities.

\section{Result}

Respondent characteristic

There were 134 specialists who were respondents of this study, coming from sample hospitals in 6 provinces: Riau, Jawa Timur, Kalimantan Barat, Kalimantan Tengah, Maluku, and Papua.

Figure 1 shows that obstetricians and gynecologists are the most respondents in this study . Figure 2 shows that many doctor specialists have their own houses, but a few doctors still rent their

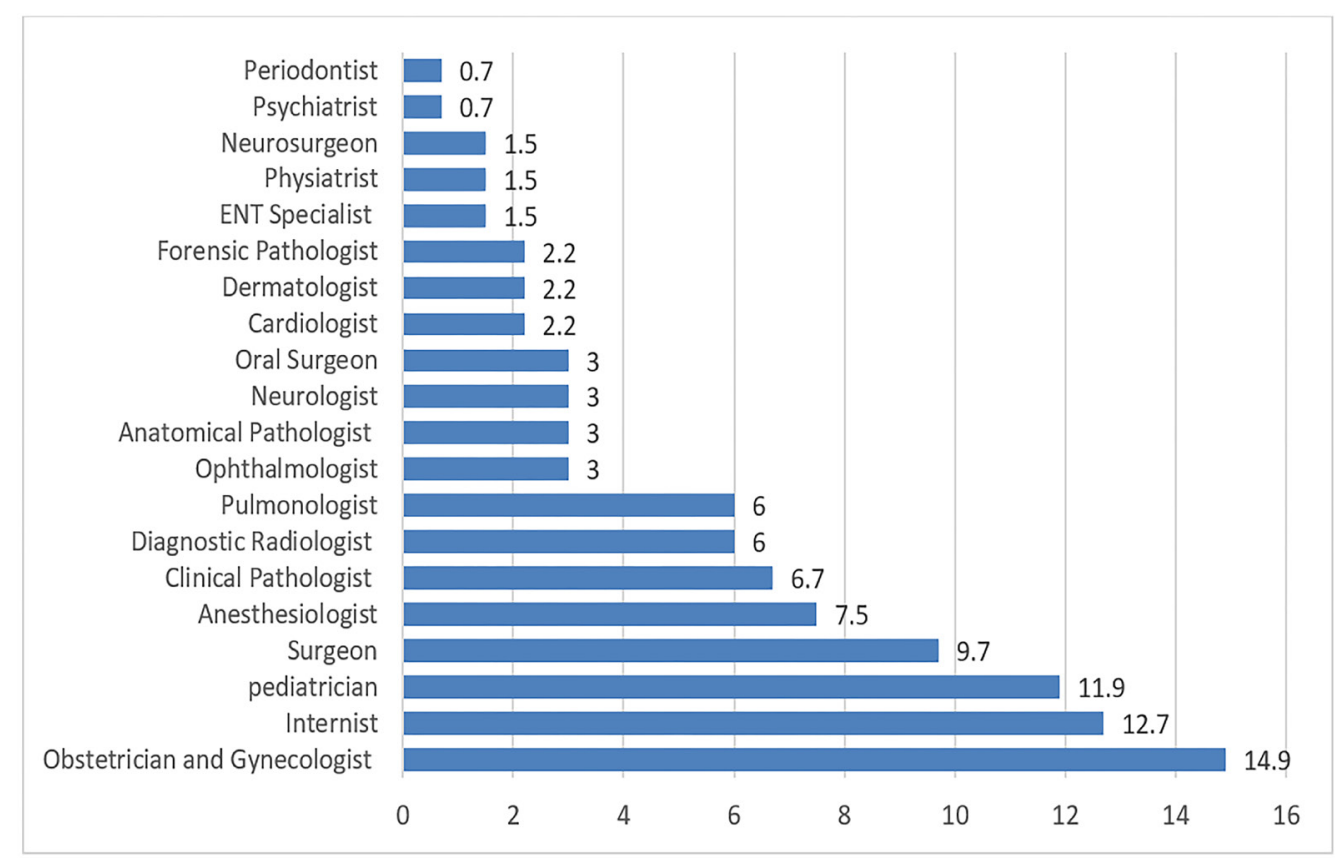

Figure 1. Distribution of Respondents According to Specialist Doctor Types $(\mathbf{N}=134)$

house or using the official residence. It is showed that non-financial incentives are still needed by specialist doctors in government hospitals, such as providing the official residence with maintenance facilities support.

From a financial perspective, most of the specialist doctors felt that they had sufficient income and most of them could savings. However, although only a small proportion of respondents, the existence of specialist doctors whose income is insufficient and or unable to saving is very unfortunate.

\section{Non-financial Incentives Specialist Doctors}

Only a small proportion of specialist doctors occupy official residences. There are still a small number of specialist doctors who occupy the official residence which is unlivable. Only a small proportion of official homes are equipped with maintenance facilities. This shows that the local government or hospital leadership is committed to providing a livable official residence, but it needs to be equipped with adequate maintenance facilities to make it livable. (Fig.2)

Official vehicles are one of the non-financial incentives that can be given to specialist doctors for ease of mobility, especially in providing health services to patients. Nearly half of the respondents have received official vehicle facilities, but only a small proportion have received fuel facilities. Fuel for official vehicles is needed to support vehicle 
operations, as well as periodic maintenance or service. (Fig 3)

Other non-financial incentives that are also important are opportunities to continue education and/or attend training. This is an effort to develop and increase the knowledge and skills of specialist doctors. Figure 4 shows that the majority of respondents stated that they had been facilitated to attend seminars/education and training. A study assignment is an assignment given by an authorized official to continue education with a scholarship. A study permit is a permit to attend education at personal expense.

Table 1. Respondent's Description of Finance and Residence Ownership

\begin{tabular}{lr}
\hline Characteristic Residence and Salary & $\mathbf{\%}$ \\
\hline Residence Ownership & \\
Private & 41,8 \\
Official residence & 28,4 \\
Rent & 16,4 \\
Family owned & 11,2 \\
Other & 1,5 \\
No answer & 0,7 \\
Income sufficiency & \\
Adequate income & 73,1 \\
Saving ability & 63,5 \\
\hline
\end{tabular}

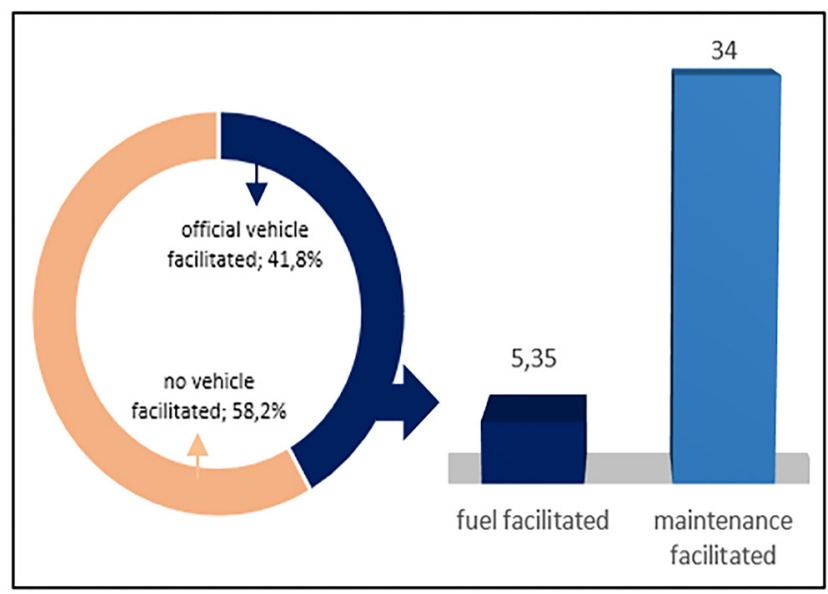

Figure 3. Distribution of Respondents According to Official Vehicle Facilities

\section{Principal Salary and Financial Incentives for Specialist Doctors}

Generally, respondents receive a basic salary every month $(\mathrm{n}=128,95.5 \%)$, while others had not received a basic salary every month $(n=6$, 4.5\%). (Table 1)

Apart from principal salaries, some regions or hospitals also provide additional financial incentives for specialist doctors. Several types of financial incentives were inventoried, including remote and border area incentives as a financial incentive given to specialist doctors in remote and border areas hospital Incentives for certain health workers as a financial incentive given to types of personnel or types of health facilities that are less desirable, performance allowances as a financial incentive given based on the results of

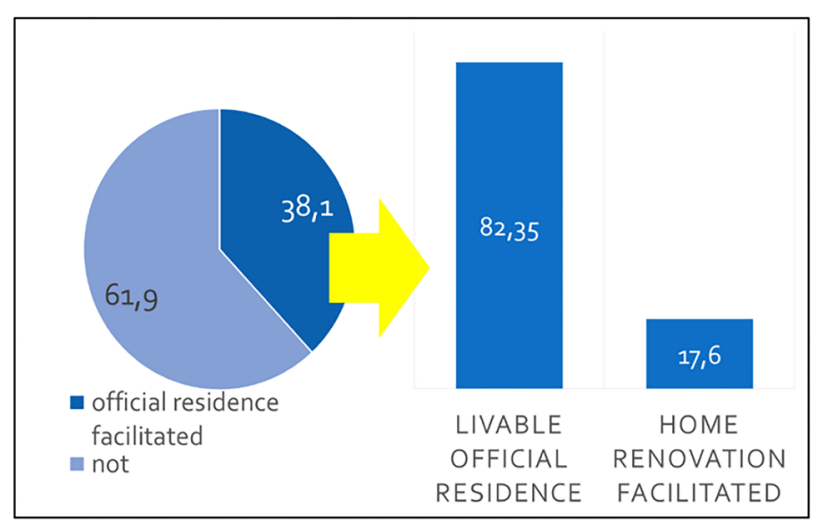

Figure 2. Distribution of Respondents According to Official Housing Facilities

performance appraisals, Medical service incentives as an incentive given to health workers in a certain regional government or hospital as an allowance for medical services provided at health facilities, a transportation allowance as an incentive provided as a transportation cost when providing health services, meal allowance as a financial incentive for the specialist doctor based on tariff and calculated daily for the food needs, overprice allowance as a financial incentive as an aid to overpriced or an increase in the price of daily necessities. (Fig. 4)

\section{Discussion}

\section{Respondent Characteristic}

There are 3 strategic issues related to health workers discussed in the Health Workforce Development Plan for 2011-2025, including 1) 
The number and type of health workers according to service standards are not sufficient, 2) Uneven distribution of health workforces, and 3) Quality is not yet evenly distributed to all health workforces. ${ }^{4}$

In this study it was seen that the most types of Specialists respondents were obstetricians and gynecologists, this is under the condition of Indonesian hospital health workforces in 2017. Based on data online from the hospital information system in 2017, it is known that the highest number of specialist doctors is obstetricians and gynecologists by $15.6 \%$ of the total number of specialist doctors, then pediatricians $13.1 \%$ and followed by internist $12.3 \%$. While the lowest number were anatomic pathologists $(1.5 \%)$, Physiatrist $(1.9 \%)$, and psychiatrist $(2.3 \%) .^{5}$

Slightly different things happen in foreign countries, obstetricians and gynecologists are not the most specialists in Singapore, although it still ranks five most. The highest number of specialists in Singapore in 2017 were anesthesiologists $(9.1 \%)$, pediatricians $(7.3 \%)$, surgeons $(6.9 \%)$, radiologists (6.7\%), and obstetricians (6.2\%). ${ }^{6}$ In other countries such as the United States, emergency specialists are at the top $(10.6 \%)$, then psychiatry $(10.5 \%)$, surgeon (10.1\%), anesthesiologists (9.5\%), and radiologists $(9.1 \%){ }^{7}$ In other countries in Europe such as Belgium, Denmark, Germany, Ireland, France, Spain, Netherlands, and Italy, surgeons and psychiatrists are more numerous than an obstetrician. Differences in the number of specialists depend greatly on the needs and characteristics of the people in each country. From the several studies, the result can be seen that there are differences in the needs of specialist doctors between Developed and Developing Countries. In developing countries, most specialist doctors are obstetricians, while in developed countries are psychiatrists, surgeons, and anesthesiologists. ${ }^{8}$ Developing countries still face various burdens of maternal and neonatal diseases, while in developed countries there is an increase in non-communicable diseases associated with various risk factors such as lack of physical activity, unhealthy lifestyle, emotional mental disorder (stress), as well accident-related behavior and injuries.

Based on this, for planning the type and number of specialist doctors, several things should be considered, such as disease control priorities, population ratio, disease patterns, population demographics (age, sex, and productivity), as well as current availability and projected demand in health facilities.

\section{Non-financial Incentives Specialists}

The incentives given to health workforces are generally financial and non-financial. Most incentives are monetary financial but at the same

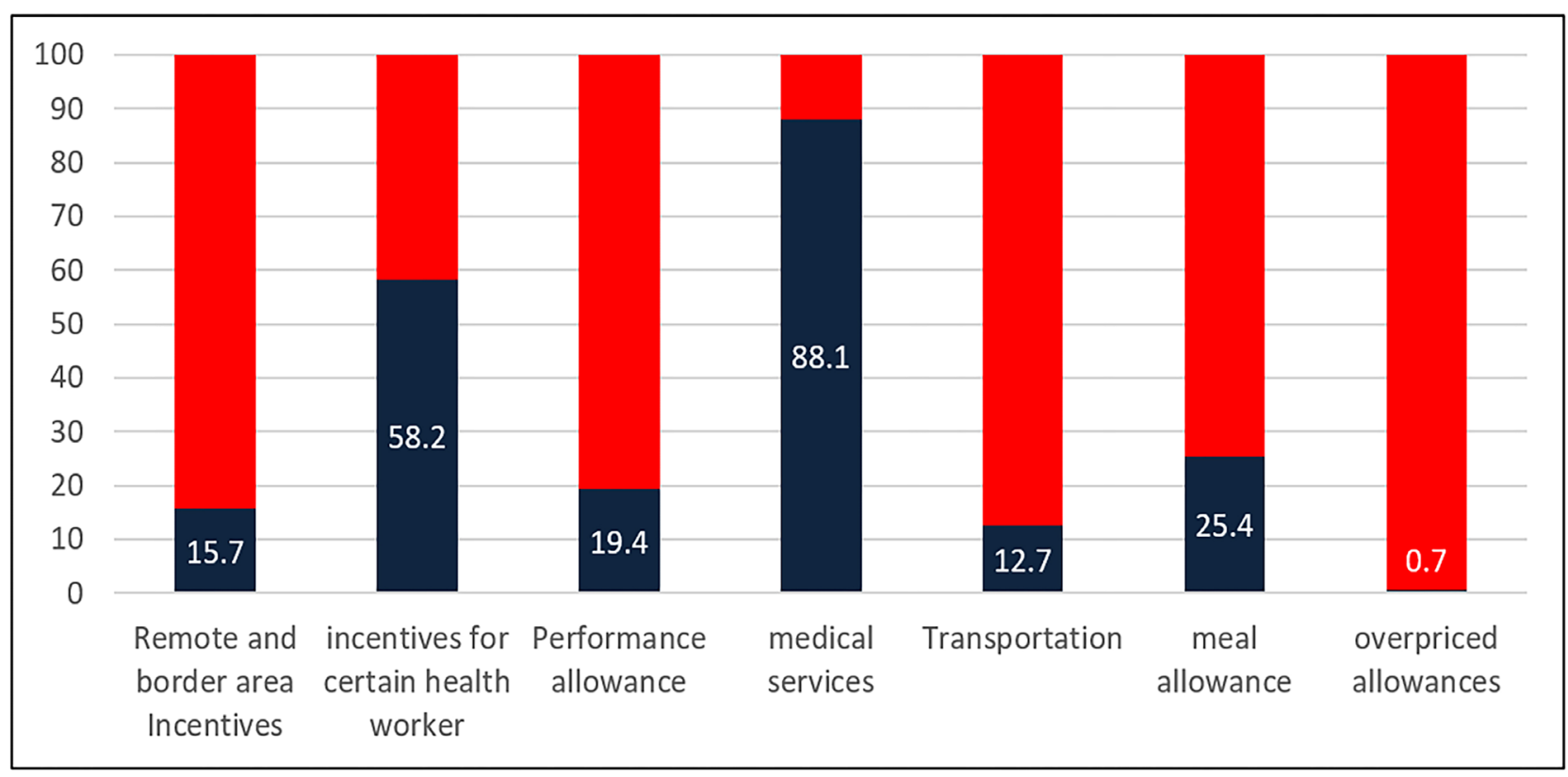

Figure 4. Types of Health Workers Incentives 
time, non-financial incentives are also given. The review shows that non-financial incentives are often combined with monetary financial incentives, such as the provision of official housing with salary increases (in Zambia); or communication facilities and allowance in mountainous areas (in Lesotho). Non-financial incentives can affect the peace of health workforces in carrying out their duties, large financial incentives do not provide more benefits if not accompanied by adequate non-financial incentives. ${ }^{9}$

This study presents a description of the nonfinancial incentives received by specialist doctors. Non-financial incentives given to health workforces in other countries such as holidays, flexible working hours, access to training, continuing education, paid leave, career path certainty, occupational health counseling, and recreational facilities. Incentives that meet social needs are used in several countries, such as: Providing housing facilities in Lesotho, Mozambique, Malawi, and Tanzania; Transportation support for health workforces in Lesotho, Malawi, and Zambia; child care facilities in Swaziland; free food in Mozambique and Mauritius; and employee support center in Lesotho. ${ }^{9}$

In this study, the description of non-financial incentives is the availability of housing facilities, operational vehicles, and educational development facilities for specialist doctors. This type of nonfinancial incentive is a supporting facility that can support motivation in providing quality health services to patients in hospitals.

The distribution of respondents according to official housing facilities in this study shows that most specialist doctors did not get an official housing facility. This is consistent with the description of respondents' characteristics, even though most of the specialist doctors already have private homes. In some countries such as Lesotho, Mozambique, Malawi, Zambia, and Namibia, housing facilities as a non-financial incentive area subsidized housing schemes or housing allowances, subsidized rental homes, or official houses that are equipped with renovation facilities. ${ }^{9}$

The results show that $41.8 \%$ of specialist doctors who were respondents in this study had received official vehicle facilities, but only $5.35 \%$ received fuel facilities, and $34.0 \%$ received facilities for periodic vehicle maintenance. This shows that operational support for specialist doctors is inadequate. In other countries, support for transportation facilities varies, transportation facilities in Lesotho are provided to transport health workforces who return late at night, transportation facilities in the State of Malawi are provided for visiting families and shopping, Zambia is also provided transportation for health workforces. ${ }^{9}$

Apart from the regular salary amount, health workforces are generally not satisfied if there are no additional incentives or benefits, especially to cover transportation costs. In other countries, especially those with large and difficult areas, many health workforces find it very difficult to reach workplaces due to poor roads and lack of transportation options, so the availability of housing facilities and transportation support is urgently needed. ${ }^{10}$

Non-financial incentives that are also expected by specialist doctors besides official residence and transportation facilities are opportunities to develop themselves through seminars, training, or continuing education. The description of specialist doctors who received seminar and training facilities was $73.1 \%$, and $38.0 \%$ had the opportunity to continue their education, even though a small proportion (11.2\%) only received study permits at personal expense. The opportunity to obtain seminars, trainings, and continuing education facilities is one of the non-financial incentives that have the benefit of improving the quality of specialist doctors and efforts to add credit points for the process of specialist certification. Some non-financial incentives such as difficulty allowances, housing, free transportation, free vacation opportunities plus innovative compensation also need to be given to specialists who work in remote areas. Educational facilities, transportation, and security are important issues to support the presence of doctors, especially specialist doctors. ${ }^{11-13}$

Non-financial incentives such as official homes can be coordinated by the local government to facilitate official housing for health workers who need them in the area. Financial incentives should consider the ability of specialist doctors to own a house in their region. Operational vehicles for specialist doctor services are not necessary, because specialist doctor services needs depend on hospital 
service facilities, except in certain cases that require the presence of a specialist outside the hospital. This can be facilitated by providing hospital operational vehicles other than ambulances that can be used. The opportunity to continue education for specialist doctors is not very important, it needs more seminars and training. however, if needed, continuing education facilities can collaborate with the central government, either from the ministry of health or the ministry of education or other scholarships. The government can facilitate by submitting scholarship offers and assisting in the administrative process. However, when specialist doctors leave the service to continue their education, it is necessary to think about a backup specialist who can provide health services.

Principal salary and financial incentives for specialists

A doctor's job is noble and responsible to uphold the highest ethical standards in medical services. These obligations and responsibilities need to be accompanied by a guarantee of a good life for the doctor. The income earned by doctors in practicing varies greatly, depending on the workload and skills possessed. Data from ZipRecruiter noted that the average annual salary for doctors in the United States was IDR 31.761.221,49 in 2018, with the highest salary in the range of IDR.53.693.309 and the lowest in IDR 3.329.268,5. Most doctors earn an annual income of between IDR 2.157.300.000 and IDR 4.487.184.000. Other data from Medscape's 8th Doctor Compensation Report for 2018 states that the average primary care physician earns IDR 3.207.186.000 annually. Meanwhile, specialist doctors earn an average of IDR 4.731.678.000 in 2018. In all specialties, Medscape found that the average salary for doctors was IDR 4.300.218.000. The numbers have risen considerably from 2017, when primary care doctors averaged IDR 2.936.010.000 in professional income, while specialists averaged IDR 4.275.480.000. Overall, the annual salary of doctors increased from an average of IDR 1.700.000.000 in 2011, IDR 4.300.218.000 in 2018. ${ }^{14}$

Compared with the results of this study, the average income of specialist doctors in the western region is IDR 348.099 .840 , in the middle region is
IDR 399.500.310 and in the eastern region is IDR 471.858 .750 , obviously smaller than the average income of specialist doctors in the USA at the same year. The average income of specialist doctors is getting east will be even greater, although the income of specialist doctors is highest in the Western Regional. The income of specialist doctors in the eastern region is higher due to the small number of specialist doctors, compared to the Western Regional, so that community choices are limited. Regional differences in doctor earnings also occur in the USA. According to the Medscape survey in 2017, there are significant doctor wage gaps between states. In mid-western states (mainly Illinois, North Dakota, Minnesota, and Wisconsin), doctors earn an average of IDR 4.316.070.000 per year, but in the Northeast US, including states such as Massachusetts and New York, where the population is dense and health care choices abound, doctors' income is only an average of IDR 3.720.750.000 per year. ${ }^{14,15}$

Adoctor's income is influenced by economic factors such as demand, expertise, skills, and age or experience. In the field of health care, the more patients, the more income earned. Diversification of expertise possessed by specialist doctors in providing services can also obtain a greater income. Quickly making adjustments or approaches with patients will increase the number of patients as well as the ability to negotiate with hospitals, clinics, or other specialist medical services on more favorable terms, pay attention to contracts and regularly try to update them. Doctors who are experts in certain medical care fields, such as radiology, cardiology, or oncology and who have a track record of gathering new patients for hospital, can substantially increase their annual income. ${ }^{14}$

The results showed that the majority $(70.9 \%)$ of specialist doctors also provided independent practice services besides their practice in hospitals. Compared to the other two regions, specialist doctors in the western region (Jawa and Sumatera) are the ones who provide the most private practice services. This relates to the need for services in the western region which may be greater than the other two regions, as well as the high ability of the people in the western region to access specialist independent practice services. Besides, the health service system in the government health insurance 
system does not allow the public to directly get the services of specialist doctors and must go through a referral. While the behavior of accessing specialist health services is still quite high in urban areas, in this case, more in the western region, so the need for specialist independent practice is still quite high. The existence of the independent practice of this specialist doctor can increase income, from the study results it is known that the highest average income from independent practice is in the western region. ${ }^{16}$

In addition to salary, financial incentives are also needed by health workforces, especially specialists. Specialists are one of the main components of the health care system. In the national social security system, specialists become downstream in the referral system hierarchy and refer to the continuum of care, specialist doctors provide the highest level of services and provide recommendations for plenary services. The results of research conducted by Gadjah Mada University (2011) indicate that the policy on the distribution and regulation of income of doctors and specialist doctors in Indonesia does not cover all the main variables that play a role in the distribution mechanism and the regulation of doctor's income. ${ }^{12}$

Research conducted by Pembantjanawati (2008) at Blora Regency Hospital concluded that the suitability between work risks and the incentives received would be effective if there was an assessment of performance, there was a review for determining the allocation of the percentage of direct and indirect incentives, there was a risk assessment following the criteria set by the system and add other risks that do not yet exist in the system, such as psychological, social, legal, violence and malpractice aspects. Conformity between workload and justice with the incentives received is effective if the work is carried out according to duties, according to the agreed workload criteria in the existing system, there is no discrimination, there is a review of direct and indirect percentages, there is a review of seniority criteria and there is clarity in distribution of workload. Suitability incentives are also related to local regulations regarding tariffs and service delivery that are in line with hospital minimum service standards. ${ }^{17}$

Financial incentives are remuneration received by employees from companies in the form of salaries, wages, bonuses, premiums, holiday benefits, old-age benefits, medical treatment or insurance, and others of the same type. In addition to salaries, the financial incentives described in this study include incentives for remote border areas, incentives for certain health workers, performance allowances, medical services, transportation costs, food allowances, and overheads benefits. Research conducted by Gadjah Mada University (2011) shows that there are already policies in the local government related to financial intensive provision for specialist doctors. In Kalimantan Timur Province, financial support is provided in the form of scholarships, and developing an incentive system for doctors both civil servants and non-permanent employees. ${ }^{12,18,19}$

Most of the specialist doctors in the study had received medical service incentives, but only 1 person $(0.7 \%)$ received an overpriced benefit. The central government only regulates the incentives of specialist doctors in the framework of the specialist doctor empowerment program. Funding in the context of a specialist doctor empowerment program includes costs needed to fulfill the total needs. The calculated cost component includes distribution/ placement costs, salary costs calculated annually referring to the number of civil servant salaries, and incentives for placement in remote areas, borders, and islands. The granting of incentives is entirely under the authority of the Regional Government. In the specialist doctor empowerment program, benefits are provided by placement hospitals and specialist doctors participating in the specialist doctor empowerment program receive incentives from the Local Government sourced from the Regional Revenue and Expenditure Budget. ${ }^{20,21}$

Research conducted by Ayuningtyas (2006) in one Province shows that the incentive system has not been well developed in all regions. The provision of incentives is uneven and highly dependent on regional capacity. For example, the provision of incentives for specialist doctors in one province, but the value varies between districts or cities. Special incentives for specialist doctors in Lampung Utara Regency are IDR 250,000 per month and Lampung Barat Regency are IDR 1,000,000 per month. There are differences in the provision of incentives between regions and there is no assessment yet whether the incentives can meet the needs of specialist doctors 
in the area. Implementation strategies and incentive delivery systems in each region ultimately depend on the characteristics of the region and the ability of local governments, both in terms of the type and number of incentives provided. Then the description obtained in this study regarding the number and types of incentives finally varies. ${ }^{4,22}$

In this study, the welfare of specialist doctors is indirectly seen based on the perception of the adequacy of income received and the ability of specialist doctors to save a portion of their income. From the results, it can be seen that there are still specialist doctors who feel that their income is not sufficient for their daily needs and cannot save part of their income. Research on the effect of financial incentive variables on work productivity shows that financial incentives have a positive effect on work productivity. The well-being of specialist doctors is also one of the variables that are indirectly related to financial incentives. Conditions of inadequate need or conditions where specialist doctors cannot save part of their income can have an impact on productivity in the workplace, for example, by making an effort to find additional income or even move to another hospital or other more promising area. $^{18}$

Incentives doctors are one of several factors that can affect the services provided, both in terms of quantity, composition, quality, and value of health care services they provided. ${ }^{23}$ Financial and non-financial incentives are important for the sustainability of services in health facilities. Directly or indirectly, financial and non-financial incentives affect the welfare and survival of doctors in health facilities. Improved financial and non-financial incentives provided to specialist doctors will indirectly improve the referral system in Indonesia, vice versa, well-functioning referral hospitals might provide the specialist doctor with a good incentive. The incentives of referral hospitals, district hospitals, and primary health care services need to align. It can be achieved through an integrated management structure and requires a good deal of communication, collaborative planning, and collaborative development. A single, global budget controlled by an authority that is concerned with optimizing the cost-effectiveness of health care delivery would seem to be a necessary condition to achieve alignment across service levels and formulate appropriate financing mechanisms. ${ }^{24}$ Financial and non-financial incentives, especially for specialist doctors in government hospitals, are very dependent on the financial capacity of the central and local governments, in addition to the financial capacity of hospitals. Therefore, calculations are needed to obtain a combination of central and regional budget capabilities, so that financial capacity can be optimized to provide adequate and equitable incentives to maintain specialist doctors in government-owned hospitals, especially in areas that are not in demand and with budget constraints.

\section{Limitation}

This study has limitations because the information provided is only based on the recognition of specialists and is not validated by supporting documentary evidence or observations.

\section{Conclusion}

Official housing and official vehicles are non-financial incentives needed by specialist doctors to get a decent life while providing medical services, but only a small proportion of specialist doctors get it. Seminars, training, and continuing education are non-financial incentives needed by specialist doctors to increase their knowledge, skills, and personal development. Most of the specialist doctors have had the opportunity to attend seminars and training, but a small proportion not have the opportunity to continue their education yet. Financially, most specialist doctors already have sufficient income and can be saving it, but the financial incentives received by specialists still vary widely, with maximum values up to 17 times minimum values. The most financial incentives received are medical service allowances and the least is overpriced allowances.

\section{Recommendation}

Several things such as diseases control priorities, population ratio, disease patterns, population demographics (age, sex, and productivity), current availability, and projected demand of specialist doctors in health facilities should be considered in the planning process the type and number of specialist doctors. Nonfinancial incentives such as official residences can 
be coordinated by the local government. Financial incentives budgeting should consider the ability of specialist doctors to own a house in their region. Operational vehicles are not necessary for specialists and it can be facilitated by providing hospital operational vehicles other than ambulances that can be used. Continuing education facilities can collaborate with the central government, either from the ministry of health or the ministry of education or other scholarships. Improvement of financial incentives can be achieved through an integrated management structure and requires a good deal of communication, collaborative planning, and collaborative development. A single, global budget controlled by an authority that is concerned with optimizing the cost-effectiveness of health care delivery would seem to be a necessary condition to achieve alignment across service levels and formulate appropriate financing mechanisms. It is needed to obtain a combination of central and regional budget capabilities so that financial capacity can be optimized to provide adequate and equitable incentives.

\section{Author Contribution}

A.L.S, H.H and A.S. contributed to the design and implementation of the research, to the analysis of the results and to the writing of the manuscript. All authors read and approved the final article.

\section{Acknowledgment}

Our gratitude goes to the head of the Center for Health Resources and Services Research and Development, along with the management and head of the Health Human Resources Development Agency who have provided guidance and assisted in the operation of this research activity as well as fellow researchers and provincial and district health offices who have assisted this research activity.

\section{References}

1. Indonesia, Undang-Undang No. 36 Tahun 2014 tentang Tenaga Kesehatan.

2. Indonesia, Undang-Undang No. 5 Tahun 2014 tentang Aparatur Sipil Negara.

3. Sumantri U. Program Pemenuhan Tenaga Kesehatan. In: Rakerkesnas 2017. Jakarta; 2017.
4. Global Health Workforce Alliance, GIZ. Rencana Pengembangan Tenaga Kesehatan Tahun 2011 - 2025. Jakarta; 2011.

5. Slamet S. Kebijakan Kementerian Kesehatan dalam Pengaturan Dokter dan Dokter Gigi di Era Global. [Powerpoint presentation]. Presented at the; 2018; Makassar.

6. Singapore Medical Council. Annual Report 2017. Vol 21.; 2017.

7. Elflein J. Physician Specialty Data Report. [Internet]; 2019. [cited April 15 2020]. Available at : https://www.statista.com/statistics/209424/ us-number-of-active-physicians-by-specialtyarea/. Published 2019.

8. European Commission. Healthcare personnel statistics-physicians. Eurostat. 2017;28(August):1.

9. Dambisya MY. A Review of Non-Financial Incentives for Health Worker Retention in East and Southern Africa. [Internet]; 2007. Available at: https://chwcentral.org/wp-content/ uploads/2013/07/A-review-of-non-financialincentives-for-health-worker-retention-in-eastand-southern-Africa.pdf

10. Bhatnagar A. Determinants of Motivation and Job Satisfaction among Primary Health Workers: Case Studies from Nigeria and India [dissertation]. Baltimore, Maryland: John Hopkins University; 2014.

11. Christianson JB, Leatherman S, Sutherland K. Paying for Quality: Understanding and Assessing Physician Pay-for-Performance Initiatives. Princeton: The Robert Wood Johnson Foundation; 2007.

12. Meliala A, Trisnantoro L. Penyebaran dan Pendapatan Dokter Spesialis Pemerintah di Indonesia. In: The Second National Forum: Indonesian Health Policy Networks. ; 2011.

13. Priyatmoko H, Lazuardi L, Hasanbasri M. Analisis determinan ketersediaan dokter spesialis dan gambaran fasilitas kesehatan di RSU pemerintah kabupaten/kota Indonesia (analisis data rifaskes 2011). J Kebijak Kesehat Indones. 2014;03(04):175-182. doi:10.22146/ jkki.v3i4.25532

14. O'Connell BO. The Average Doctor Salary by State and Specialty What is an Average Salary of a Doctor? Physician Incomes by Specialty 
Key Trends in the Physician Field That Impact Income Potential. TheStreet [Internet]. 2018 [cited April 14 2020]. Available at: https://www. thestreet.com/personal-finance/how-much-dodoctors-make-14779617 1/3

15. Bank Indonesia. Laporan Perekonomian Indonesia Tahun 2017. Jakarta: Departemen Komunikasi Bnak Indonesia; 2018.

16. Rutten FFH, Van Der Gaag J. Referrals and demand for specialist care in the Netherlands. Health Serv Res. 1977;12(3):233-249.

17. Pembantjanawati EK, Meiyanto S, Meliala A. Evaluasi Sistem Remunerasi Di RS Dr. R. Soetijono Kabupaten Blora. Blora [Powerpoint presentation]; 2008.

18. Irawati P, Suwendra IW, Yulianthini NN. Pengaruh Kompensasi Finansial dan Non Finansial Terhadap Produktivitas Kerja Karyawan. e-Journal Bisma Univ Pendidik Ganesha. 2014;2(1):632-642.

19. Kalimantan Timur, Kepala Dinas Kesehatan Kalimantan Timur. Dukungan Pemerintah Daerah (Insentif Finansial dan Non-Finansial) dalam rangka Pemerataan dan Retensi Dokter dan Dokter Spesialis di Provinsi Kalimantan Timur. [Powerpoint presentation]. Yogyakarta: Fakultas Kedokteran Universitas Gadjah Mada;
2013.

20. Indonesia, Kementerian Kesehatan. Peraturan Menteri Kesehatan RI No. 14 Tahun 2018 tentang Program Bantuan Pendidikan Dokter Spesialis-Subspesialis Dan Dokter Gigi Spesialis-Subspesialis.

21. Hutauruk CJH. Faktor-Faktor yang Memengaruhi Pemilihan Karier sebagai Dokter Spesialis pada Dokter Muda Fakultas Kedokteran Universitas Lampung. [skripsi]. Lampung: Fakultas Kedokteran Universitas Lampung; 2017.

22. Ayuningtyas D. Sistem Pemberian Insentif yang Berpihak pada Sumber Daya Manusia Kesehatan di Daerah Terpencil: Studi Kasus Provinsi Lampung. J Manaj Pelayanan Kesehat. 2006;9(2006):87-93.

23. Clemens J, Gottlieb JD. Do Physicians' Financial Incentives Affect Medical Treatment and Patient Health? Am Econ Rev Author manuscript; available PMC. 2014. doi:10.1257/ aer.104.4.1320

24. Jamison DT, Breman JG, Measham AR, et al., editors. Disease Control Priorities in Developing Countries (Second Edition). 2 nd. New York: Oxford University Press; 2006. doi:10.1596/978-0-8213-6179-5 